\title{
Crisis, State and Health Care Entitlement in Recent Brazil: A Pachukanis' Critical Approach
}

\author{
Leonardo Carnut ${ }^{1}, \&$ Áquilas Mendes ${ }^{2}$ \\ ${ }^{1}$ Universidade Federal de São Paulo (UNIFESP), São Paulo, Brasil \\ ${ }^{2}$ Universidade de São Paulo (USP) e Pontifícia Universidade Católica de São Paulo (PUC-SP), São Paulo, Brasil \\ Correspondence: Leonardo Carnut, E-mail: leonardo.carnut@unifesp.br
}

Received: July 12, 2021

Accepted: August 16, 2021

Available online: August 30, 2021

doi:10.11114/ijsss.v9i5.5289

URL: https://doi.org/10.11114/ijsss.v9i5.5289

\begin{abstract}
This article discusses the nature of the capitalist crisis and its effects on the dismantling of the hard achievements of the universal health care entitlement in recent Brazil. It performs an analysis based on the limits of Brazilian state's action, organically linked to capital movement and its crisis, particularly on 'legal form'. In order to deepen this subject, it is based on the theoretical perspective of Pachukanis' General Theory of Law, emphasizing its analysis on the difficult coexistence between public and private law, in order to understand the crisis of the right to health care.
\end{abstract}

Keywords: state, form-politics, legal form, right to health

\section{Introduction}

In these evil times of contemporary capitalism, there is often a successive annihilation of social rights in general, and particularly of health care entitlement. This adventurous and disastrous capital targeting seems to be endless in the world, and more intensely in Brazil, especially after the 2016 Institutional Coup that removed President Dilma Roussef. It is to be expected that this calamitous scenario has led the Unified Health System (SUS), over the course of 31 years of its existence, along tortuous, conflict-ridden paths, in which privatizing management models and financial unsustainability increasingly penetrate its interior and assume its main brand.

To what extent this tragic picture to the confirmation of the universal health care entitlement in Brazil can be explained by the presence of the crisis of capitalism or by the very logic of the constitutive aspects of capitalist sociability?

This question leads us to the necessary task of addressing, in this article, the two central aspects of it, namely, the nature of this capitalist crisis and its rebounds in the dismantling of the hard won achievements of the universal right to health care, as well as elucidating the limits of the State action - with an organic link to the movement of capital - weakening the defense of the right to health. This is because we understand, as Pachukanis (2017, p. 124), the difficult coexistence between "law as synonymous with the official structure of the state and as the slogan of revolutionary struggle". Pachukanis was a Soviet jurist, murdered by Stalin, and who, in the 1920s, wrote the book General Theory of Law and Marxism, developing an original idea within Marxist thought regarding the role of law and the state in capitalist and post-capitalist society.

According to this understanding, this article was sub-divided into three sections. The first section presents the most general features of contemporary capitalist crisis, in order to better understand its influence on the weakening of the universal health care entitlement in Brazil. In the second section, we analyze the role of the state, taking it as part of the capitalist relations of production, being derived from the dynamics of capital, based on a critical perspective of Evguiéni Pachukanis. In this sense, in this part, the general ideas about law are also discussed, in the view of this author, who seeks to demystify the opposition between private law and public law. The third section deals with aspects of limiting the defense of the health care entitlement when inserted in the imbricated form of public and private law constituting capitalist sociability.

\section{Brief Notes on Contemporary Capitalist Crisis and Health}

The meaning of the public health crisis in Brazil deserves to be understood as an integral part of the crisis of capitalism in its determining social forms: the crisis of the commodity form, with regard to the accumulation and valorization of value; 
the crisis of the state political form, the growing "privatizing modalities of social policy management" and thepermanent fiscal adjustments; and, also, the crisis of the legal form according to the state political form, highlighting the crisis of the law form (Mascaro, 2018; Pachukanis, 2017b), in particular, the health care entitlement. The foundations of the meanings of the health crisis are constitutive of the long historical time of capitalism after the 1980s and of its determining forms of crisis sociability.

In the contemporary scenario, so far, a full recovery of the capitalist economies, including the Brazilian one, has not been perceived. The crisis has lasted for about eleven years since the crash of the great recession of 2007/2008, according to what Roberts (2016) calls a period of "long depression". It is noteworthy that capitalist economies have collapsed and are still struggling to recover, especially in relation to productivity and the behavior of production.

What we want to reinforce here is Marx's (2017) understanding of the capitalist crisis, which is a crisis of overaccumulation and overproduction. When referring to the crisis, Marx guides us in the sense that the dynamics of capitalism always develops accumulating contradictions and that periodically lead to crises (Marx, 2013). From Marx's teachings, Callinicos (2014, p. 236) insists that "we can find in the book Capital not a complete articulated theory of crisis, but a multidimensional conception of economic crises and their place in the capitalist mode of production".

From this perspective, this author proposes that the determinations of the crisis can be grouped into three categories, in an integrated dimension. The first refers to factors that enable the eruption of crises arising from the exchange of goods, the modern capital credit system and the exchange conditions [expanded reproduction] between the two main production departments [production goods and consumers goods] required for system playback. The second category brings together factors that condition the emergence of imbalances resulting from the interactions between fluctuations in wage rates and the size of the industrialreserve army, together with the rotation of fixed capital. The third category relates to the causality of crises, hence Marx's specific treatment of the law that expresses the conflict between forces and relations of production and the most fetishized form of capital, the law of the tendency of the rate of profit to fall and the bubble and panic cycle in the financialmarkets, known today for the significant presence of fictitious capital.

Callinicos' multidimensional notion seems quite complete to us for understanding the totality of capital movement and its imbricated crisis. For the purposes of our analysis, we give priority to its third category. Thus, we understand that the contemporary crisis ofcapitalism, especially from the years 1970-1980, is anchored in the articulation of two main trends, namely: the tendency of the rate of profit to fall in capitalist economies, with emphasison the later period of World War II; and, in response to this tendency, the capitalist system enters the path of financial appreciation, in which interest-bearing capital, its most perverse form, fictitious capital, becomes the leader in the dynamics of capitalism in this period, appropriating public funds (Chesnais, 2016).

According to Kliman (2012), the profit rate in the United States, particularly in the corporate sector of industrial and financial companies, dropped from just over $20 \%$ in 1950 to below $7 \%$ in 1982, fluctuating in this position from then until the 2000s. This drop has also been observed in the movement of the world average of the rate of profit in the capitalist economies (Choonara, 2019).

Although, since 1980, a slight recovery of the profit rate in these economies has been observed, it was insufficient to restore the level observed in the early years of World War II (Kliman, 2012). On the other hand, the existence of a small recovery of the profit rate after the1980s was due to the neoliberal economic policies that, as we know, have been reducing workers' wages, establishing even more precarious working conditions and imposing risks to social policies, particularly universal health systems, from drastic cuts in spending. At the same time, new contradictions have arisen, hardening competition in the world and increasing pressure on wages and social rights in countries.

It is from this perspective that we can understand the nature of contemporary capitalist crisis of the commodity form, with regard to the accumulation and valorization of value (value-form). This crisis has intensified the attacks and harshly questioned the welfare state, directingit more straightly to market interests and the privatization processes of public health policies.

From the 1980s onwards, it appears that a growing part of undistributed profits was directed to the financial sphere, which led to the overwhelming growth of fictitious capital, whether in the form of government bonds, shares traded on the secondary market or derivatives of all kinds (Chesnais, 2016). In this scenario, the emergence of the second trend of capitalist accumulation in the last 40years is understandable: the supremacy of interest-bearing capital, commanding the center ofeconomic and social relations, leading to the expansion of fictitious capital - a kind of counter-trend tendency of the rate of profit to fall. Between 1980-2013 global financial assets increasedsignificantly, from nearly U\$ 12 trillion to U\$ 285 trillion, respectively (Mckinsey Global InstituteReports, 2013). During this period, this extraordinary expansion considerably outperformed world GDP growth.

Chesnais (2016) warns that the slow pace of world GDP growth contrasts both with the intensity of labor exploitation in 
factories in industrialized and non-industrialized countries, and with the amount of what is considered money moving ceaselessly across the world financial system. The result is that the logic of fictitious appreciation, ultimately ensured by states via public debt issuance, has been expanding.

It should be highlighted that the interaction of these two causal trends that explain the contemporary crisis articulates with the political form, or the state, as it is itself an integral part of the capitalist relations of production, in order to ensure the value form of capital. It is no wonder that state budgets, especially the Brazilian one, have been committing to the issuance of more public debt securities and the substantial growth in public debt service payments. Between 1995 and 2015, the spending of the Ministry of Health (MoH) remained unchanged at $1.7 \%$ of GDP, while spending on debt interest represented, on average, $7.1 \%$ (Mendes, 2016).

\section{The Crisis and the Political-Legal Forms of the State and the Legal Form}

The state plays a role in the movement of capital that confirms its capitalist nature. It is to say that the state is the guarantor of maintenance and producer of the relation of production. However, commodity exchange and the extension of the commodity form to the labor force (with the generalization of the commodity) mean that this relation of production does not appear as such. Thus, it is understood that the state is present, ensuring that the apparently egalitarianrules of exchange are not violated (Pachukanis, 2017b). Thus it is illusory to think that the capitalist state appears to be neutral and above civil society. There is, therefore, an intertwined nature of the state with capital.

The succession of the "commodity/value/money" categories cannot end in the "capital" category. This is because, if limited to the category "capital", this logical deduction does not allow us to grasp in its entirety the causes of the real movement of capitalist sociability. Capital cannot be conceived if the category "State" is omitted. The category "capital" goes beyond itself and the State cannot be understood without resorting to the preceding categories. The state is deduced, that is, derived from the logic of capital (Pachukanis, 2017b).

According to Pachukanis (2017b, p.175), the state plays its role of coercion to ensure capitalist sociability. For him, such coercion is "coming from some general abstract person, as coercion performed not in the interest of the individual from whom he comes - for every man in mercantile society is a selfish man -, but in the interest of all participants in legal exchange".

Mascaro's contribution (2013, p. 18) adds to this reflection when he says that: “[...] the state reveals itself as a necessary apparatus for capitalist reproduction, ensuring the exchange of goods [...]", in its value-form " $[\ldots]$ and the very exploitation of the labor force in wage labor". It is admitted that "the state is not bourgeois by the will of its agents, but by the material nature of its social form" (Mascaro, 2018, p. 26). However, it is important to note that between the value form and the state political form there is neither a necessary logical unfolding nor full functional linkage. Mascaro (2013) still argues that the political and the legal are established in the totality of the production relations, being intertwined in a dialectical way, although with the leadershipof the latter in relation to the process of constitution of sociability.

In this perspective, it is not admitted conceiving the State as something external to capital or civil society, especially to the effects of the dynamics of contemporary capitalism and its crisis with attacks on social rights in general and health in particular. From this perspective,we understand that the contribution of the 1970s derivation debate that deduces (derives) the "political form" or "state form" from the contradictions of the dynamics of capital is important, in which the nature of this relationship attributes to the state its capitalist nature, ensuring the exchange of goods in their value form and the exploitation of the labor force itself (Bonnet \& Piva, 2017).

It is then a question of understanding the capitalist crisis by reinforcing the two determinant forms of capitalist sociability already analyzed so far, namely the commodity-form/value-form and the state political form, adding a third one: the legal form (or contractual form) in accordance with the need to ensure production relations (Mascaro, 2018). The latter also goes into crisis, putting social rights - such as health care entitlement - that is to say reducing them. This is noticeable when analyzing the meanings of the "Reforms", or rather "Counter-Reforms" that the capitalist state has been adopting in the context of contemporary capitalism in crisis and its deleterious effects on social policies, of which health policies are the concrete expressionof this right (Mendes \& Carnut, 2018). That is why one can refer here to the crisis of the rightform.

Before addressing, in particular, this legal form crisis in the contemporary context, particularly the right to healthcare, in the next section, it is important to understand, what Pachukanis (2017) shows us about the meaning of wholeness in the development of right to healthcare in capitalist sociability. This author admits that private law - to secure capitalist contractual relations - is generated by public law. Pachukanis argues that private law and public law (admitting them as abstract forms) are intertwined.

Pachukanis refers to the "reality" associated with the social relations of capitalist production and the "power" of capital. Roughly speaking, one can understand the tensions of guaranteeing the right to healthcare in Brazil through the process of public policies in the contemporary context - reductions of this right and its commodification - to what Pachukanis 
elucidates us by making this right fit the reality of capitalism in crisis. Pachukanis (2017b) is even clearer in his thinking:

The division between public and private law poses specific difficulties,since only in an abstraction is it possible to draw a boundary between man's selfish interest as a member of civil society and the general abstract interest of the political whole. In practice, these elements interpenetrate each other (Pachukanis, 2017b, p. 130).

Still, by demystifying the nature of the legal form, he adds the fragility of public law:

The legal form, with its aspect of subjective legal authority, arises in a society consisting of atomized bearers of private, egoistic interest... [...] since private interests cannot inherently achieve such full development and overwhelming significance in the political organization as they can in the economy of bourgeois society, therefore even subjective public rights act as something ephemeral, deprived of real roots, and are constantly in doubt.... [...] Public law can exist only as the reflection of the form of private law in the sphere of political organization, or else it ceases to be law. (Pachukanis, 2017b, p. 131-132).

When analyzing the process of legal relations, mediated by law, Pachukanis (2017a, p. 137) recognizes the subject as the most elementary category of this relationship. He says, "Every legal relationship is a relationship between subjects". It is through the "right" subject that this author begins the analysis of the legal form. We consider, therefore, in view of this methodologically coherent analysis, that it becomes possible to realize the logical deduction of the legal form from the commodity/value-form and the state political form. Now, if these last two social forms that determine capitalist sociability are in crisis, by the logic of this deduction, the legal form, through its right form, is also in crisis.

In this sense, there is no doubt that the state plays an essential role in commanding and managing counter-trends to counteract the fall in the profit rate, as already mentioned in the first part of this article. The state's character in safeguarding the form of capital is evident, placing itself at the forefront of intensifying the exploitation of the labor force, in guaranteeinginstruments that weaken hiring conditions and intensify the loss of social rights.

\section{The Right to Health Care in Brazil: a Pachukanis' Critique of Juspositivism}

Due to what has been discussed so far, we reinforce the question: how is it possible to confirm the right to healthcare in Brazil, from its universal perspective, considering the very logic of the constitutive aspects of capitalist sociability, whose bourgeois law is one of these?

However, Pachukanis (2017b) did not deal directly with health care right because his work is dedicated to the general legal form, thus constituting a General Theory of Law in light of the Marxist approach. However, we will make here the effort to bring together the elements of the general theory of Pachukanian law that, in our view, explain the nature of the legal form and, as a consequence, its implication, and reflect on the health care entitlement inBrazil as a legal norm and not on its effectiveness itself.

The health care entitlement in Brazil is legally endowed with diverse understandings, which guarantees a wide interpretative profusion, depending on the case. In the Brazilian legal system, the principle of the dignity of the human person (art. 1) in coherence with the right to life, in article 5 (of individual and collective fundamental rights and guarantees) and as Article 6 (social rights), make health care entitlement, as content, a basically 'social' right, expressed in normative terms in article 196 of the federal constitution (Brazil, 1988). This means that health in Brazil must be understood primarily as a social right, arising from the implementation of public health policies in synergy with other social policies - which extend right to health care beyond its essential core (Rios, 2013) - and that these policies order the necessary referral to be given to economic policies aiming at the material viability of this right that finds its concrete expression in SUS (Dallari, 2012).

In this sense, anchoring in juspositivism, it is said that right to healthcare is 'objective' when considering the implementation of health policies (its materiality) as an expression of the legal norm of the right to health care. Its "objectivity" would be based on the caring nature of this right, which requires a proactive state posture in financing, deciding, executing and monitoring the action and improvement of these policies. However, when the citizen does not feel contemplated by the scope of the execution of health policies, he/she can file a lawsuit, requiring the judiciary to provide health service that meets their needs. This understanding of law in juspositivism is called "subjective" law (Aith, 2007). This subjectivity is related to the individual (egoistic) needs, and therefore, unique to the person who demands the effectiveness of the right to his/her demand. In the health sector, the most exemplarycases of this type of tutelage (Sarlet, 2012) are the phenomenon of judicialization by medicines, for example (Marques, 2008).

Subjective law is a characteristic of the selfish man, a member of civil society. [...] Objective law is the expression of the bourgeois state as a whole, which 'manifests itself as a political state and realizes its universality only in opposition to its own elements'... delimit the border between man's selfish interests as a member of civil society and the general abstract interest of the political whole is possibleonly through abstractions. (Pachukanis, 2017b, p. 111). 
Thus, when considering the Pachukanian perspective on the right to healthcare, the first operation that misrepresents this right is the dismantling of the artificial dichotomy between "objective" and "subjective". Pachukanis (2017a) considers that one of the tasks of the general theory of juspositive law is to create abstractions that detach the law from a concrete reality, universalizing relationships between subjects that are generally fictional. For the author:

Thus, for example, it is common, after being given a general definitionof law, to learn that, strictly speaking, there are two types of law: the subjective and the objective, jus agendi and norma agendi. Moreover, the possibility of such a dichotomy is by no means foreseen in the definition itself, so we are either denied either by fiction, phantom, etc.,or by establishing a purely external connection between the general concept of law and its two types. However, this twofold nature of law,this decomposition between norm and legal faculty, has no less significant significance than, for example, the decomposition of commodity into exchange value and use value [...] law as form is imperceptible outside their immediate definitions. It exists only in opposites: objective law and subjective law, public law and private law,etc. (Pachukanis, 2017b, p. 75).

Therefore, juspositivism attempts to atomize the law into 'public' and 'private' law and to make it believe that the second derives from the first. Importantly, this 'inversion' is not an argument exclusively anchored in Kelsian legal philosophy or restricted to the realms of liberal thought. It can be found in socially-minded authors, as Pachukanis himself criticizes, for example, in Gumplowicz. For the latter, private law emerged from the public, however Pachukanis (2017b)identifies the problem of the Gumplowiczian method.

That is why for him [Gumplowicz], private law originated from the public law. But the fact that the main institutions of the old jus civile - family, property, and order of succession - were created by the ruling classes for the conservation of their domain may draw a diametrically opposite conclusion, namely: 'all public law was, at some point, privatelaw. This is truer - or rather false - as the opposition between private and public law corresponds to much more developed relations and thus loses its meaning when applied to primitive times. (Pachukanis, 2017b, p. 105).

Therefore, to admit health as a public and subjective right is, to a large extent, to ratify the essence of law and its source in the origin of capitalist sociability, in the needs of selfish and clear man, in the functionality of law as an abstraction necessary for transit of private and expropriating interests of one class over the other, having as its origin the civil logic.

Subjective public rights are the same private rights (and hence also thesame private interests) revived with some changes, which invade a sphere in which the impersonal general interest reflected in the norms of objective law should prevail. It stands out for its simplicity, clarity and perfection, while public theories abound with forced, artificial, unilateral and even grotesque constructions. The form of law with its aspect of subjective authorization is generated in a society consisting of isolated holders of private, selfish interests. (Pachukanis, 2017b, p. 112).

For public policy operators, subjective public rights (of which the right to health in Brazil is one of them) are difficult to operationalize and try to fit a law into a reality that does not fit, so often turn dead letter or, at best a mere 'letter of intent'. In an attempt to operate health care entitlement as a social right, the sanitarians who manage health policies are, strictly speaking, the agents of the state that promote the guarantee of health care entitlement in their primordial understanding (as a 'social right'). However, in the practice of daily management what is perceived is that right to health care as an operation of its policies has several restrictions that prevent the access and universality of the law. While the executive does not fulfill its role, the judiciary cannot make efforts beyond this realization as

$\ldots$ in the field of public law, the efforts of lawyers are generally frustrated, for power tolerates no interference in their business and does not allow in their domains the omnipotence of legal logic. It is quite obvious that the logic of legal concepts corresponds to the logic of the social relations of the commodity-producing society, and it is precisely in those relations, rather than in the resolutions of the authorities, that the roots of the system of law are worth seeking. [...] the logic of the relations of power and submission lies only in part with the system of legal concepts. Therefore, the legal concept of state can never be a theory, but will always remain as an ideological deformation of facts (Pachukanis, 2017b, 106).

Still in the exercise of health policies by the state, this time by the executive branch, a reflectionis needed. In the primordial understanding of the health care entitlement as a social right - when the interest in securing the right converges with the capitalist logic, or even below intense class struggle - it seems to be possible that policies can implement the right to healthcare. However,the 'ideological deformation of the facts', as Pachukanis points out, must reach the most operational norms. What guides its operation in the implementation of public health policies in Brazil in structural and procedural terms are the norms of public health law. Being constituted as a form (or branch) of administrative law, we can consider that its legal forms are secondary/tertiary derivations of fundamental legal abstractions. These norms of law braid an interweaving that prefigures the state as a complex normative tangle (legal superstructure) that appears to be more a hindering element of the enforceability of policies than a system of guarantees.

Marx points out that the deeper, deeper layer of the legal superstructure - property relations - is in such close contact with 
the base that it appears"only as a legal expression" of existing relations of production. The state, that is, the organization of political class domination grows on the ground of given production or property relations. The relations of production and their legal expression form what Marx, following Hegel,called civil society. The political superstructure, and in particular the official organization of the state, is a secondary and derivative moment.(Pachukanis, 2017b, p. 102).

On the other hand, administrative law in general, as the law of 'processes', demonstrates the highest degree of abstraction, seems almost sterile in meaning. However, in understanding its origin, Pachukanis asserts that this is the state's form of organization (political superstructure). These are just secondary 'momentum' norms whose function is to be the appearance that subtracts property relations. One can think of Brazil, why the Law 8.666 / 1993 (Law of contracts and bids) (Brazil, 1993) remains untouched until the present day.

Even under these difficulties, well-meaning sanitarians, who understand their role in the struggle for the guarantee and effectiveness of health care entitlement in Brazil, are still placing hope in the state and bourgeois law in the construction of universal health. As the banner of the health reform struggle and as political emancipation, it seems unreasonable to superimpose the right to health over criticism of the nature of the legal form, having it more as a way to amortize the terrible living and working conditions than as a fact to be conquered in this mode of production. However, our criticism is that, in understanding the essential derivation of the legal form, one should not place the centrality of the debate on the health care entitlement neither as an execution of politics nor as a revolutionary practice, making both paths a further decoy of the assumption of the mode of capitalist production than an anti-capitalist struggle.

Law emerges as a principle of social organization, as well as a means for individuals to 'lay the groundwork for their coexistence in society'.In one case, it is as if the law merged completely with external authority; in another, he opposes, also completely to external authority, which he does not recognize. Law as a synonym with state power and law as the watchword of revolutionary struggle are a field of endless controversyand the greatest confusion. (Pachukanis, 2017b, p. 107).

\section{Final Remarks}

In light of the Pachukanian analysis, it can be said that this tragic picture of the confirmation of the universal right to healthcare in Brazil can be explained by the presence of the crisis of capitalism, which has in the State and in law the constitutive and reproductive aspects of this capitalist sociability.

The crisis that justifies the assault on the public fund, the State as the entity that is ultimately triggered to guarantee the vitality of capital and its reproduction, has in law an ideological form that ensures the masking of social relations of production by concealing it under the veil of the State organization by rules, norms and laws, which 'derive' from the 'social consensus' on the political whole. Pachukanis shows us how much of abstraction there is in the theoretical formulation of juspositive law how functional it is to capitalist sociability.

Our approximation of the Pachukanian argument to the right to health in Brazil demonstrates how problematic is the sanitarians' trust in the undisputed defense of the right to healthcare as a source of solving problems in this sector. In a very brief analysis, we point out the limits of having in the right the hope of changing the social scenario of the health sector, even considering its essential interpretation, that is, as a social right.

Therefore, this unveiling and criticizing the nature of their legal forms can be a fruitful empirical enterprise for truly revolutionary action, helping those SUS workers to identify the limits of bourgeois law and not to commit health care entitlement as a slogan or to have it as an ideal horizon. If we must have a necessary utopia to be achieved in health, it is the overcoming of the capitalist state and the deconstruction of rights to the bourgeois mold, fighting for a classless society, no state subsidy and a truly popular health.

\section{References}

Aith, F. (2007). Curso de direito sanitário: a proteção do direito à saúde no Brasil. São Paulo: Quartier Latin.

Bonnet, A., \& Piva, A. (2017). Prólogo. In Bonnet, A., \& Piva, A. (Eds.). Estado y Capital: el debate alemán sobre la derivación del Estado. Ciudad Autónoma de Buenos Aires: Herramienta.

Brazil. (1988). Constitution of the Federative Republic of Brazil. Ministry of Education. Ministries Esplanade. Brasilia.

Callinicos, A. (2014). Deciphering Capital: Marx's Capital and its destiny. London: BookmarksPublications.

Chesnais, F. (2016). Finance capital today. London: Historical Materialism Series. https://doi.org/10.1163/9789004255487

Choonara, J. (2019). The political economy of a long depression. International Socialism. Retrieved from http://isj.org.uk/the-political-economy-of-a-long-depression/

Dallari, S. G. (2012). Direito constitucional à saúde. In Asensi, F., \& Pinheiro, R. DireitoSanitário (pp. 80-98) Rio 
de Janeiro: Elsevier.

Federal District. Brazil. (1993). Lei no 8.666, de 21 de junho de 1993. Regulamenta o art. 37, inciso XXI, da Constituição Federal, institui normas para licitações e contratos da Administração Pública e dá outras providências. Brasília, DF.

Kliman, A. (2012). The failure of capitalist production. London: Pluto.

Marques, S. B. (2008). Judicialização do direito à saúde. Revista de Direito Sanitário, 9(2), 65-72. https://doi.org/10.11606/issn.2316-9044.v9i2p65-72

Marx, K. (2013). O Capital: contribuição à crítica da economia política. Livro I. São Paulo: Boitempo Editorial: São Paulo.

Marx, K. (2017). O Capital: Critica da economia política. Livro III. São Paulo: Boitempo.

Mascaro, A. L. (2013). Estado e forma política. São Paulo: Boitempo.

Mascaro, A. L. (2018). Crise e Golpe. São Paulo: Boitempo.

McKinsey Global Institute. (2013). Financial globalization: retreat or reset? Global capital markets. Report, 2013. Retrieved from https://www.mckinsey.com/featured- insights/employment-and-growth/financial-globalization

Mendes, Á. (2016). Os impasses dos direitos sociais trabalhistas e do financiamento da seguridade social e da saúde brasileira no capitalismo contemporâneo em crise. In Souza, H. S., \& Mendes, Á. (Eds). Trabalho e Saúde no Capitalismo Contemporâneo:enfermagem em foco (pp. 15-41) Rio de Janeiro: Doc Content.

Mendes, Á., \& Carnut, L. (2018). Capitalismo contemporâneo em crise e sua forma política: o subfinanciamento e o gerencialismo na saúde pública brasileira. Saúde e Sociedade, 27, 1105-1119. https://doi.org/10.1590/s0104-12902018180365

Pachukanis, É. (2017a). A teoria geral do direito e o marxismo e ensaios escolhidos (1921-1929). São Paulo: Sundermann.

Pachukanis, É. (2017b). A teoria geral do direito e o marxismo. São Paulo: Boitempo.

Rios, R. R. (2013). O direito fundamental à saúde e atividade legislativa. Alves, S. M. C., Delduque, M. C. \& Neto, N. D. Direito Sanitário em Perspectiva. (pp. 169-180) Brasília: ESMPU: Fiocruz.

Roberts, M. (2016). The long depression: how it happened, why it happened, and what happensnext. Chicago: Haymarket Books.

Sarlet, I. W. (2012). A titularidade simultaneamente individual e transindividual dos direitos sociais analisada à luz do exemplo do direito à proteção e promoção da saúde. In Asensi, F., \& Pinheiro, R. Direito Sanitário (pp. 99-116) Rio de Janeiro: Elsevier.

\section{Copyrights}

Copyright for this article is retained by the author(s), with first publication rights granted to the journal.

This is an open-access article distributed under the terms and conditions of the Creative Commons Attribution license which permits unrestricted use, distribution, and reproduction in any medium, provided the original work is properly cited. 